\title{
Hydrochloric acid removal from the thermogravimetric pyrolysis of PVC
}

D. Torres ${ }^{a^{*}}$, Y. Jiang ${ }^{a}$, D.A. Sanchez Monsalve ${ }^{b}$, G.A. Leeke ${ }^{a, c}$

3

\section{Abstract:}

A powder characterization method was developed to screen the ability of a range of chemicals and absorbents to retain chlorine from chlorinated plastic pyrolysis. The behaviour of adsorbents such as $\mathrm{Al}_{2} \mathrm{O}_{3}$ and zeolites, and chemical removers based on $\mathrm{NaHCO}_{3}, \mathrm{CaO}$ and $\mathrm{Na}_{2} \mathrm{CO}_{3}-\mathrm{ZnO}$ were studied for the removal of $\mathrm{HCl}$ released during PVC pyrolysis. First, chlorine removers are mixed with PVC and tested in a thermobalance under pyrolysis conditions for the complete PVC dehydrochlorination $\left(550^{\circ} \mathrm{C}\right)$. Subsequently, after the release of $\mathrm{HCl}, \mathrm{CO}_{2}$ and $\mathrm{H}_{2} \mathrm{O}$, the chars are analysed by FTIR, CHN elemental analysis and ESEMEDS to determine the retention of chlorine on the chlorine removers. According to FTIR and CHN, PVC pyrolysis occurs through dehydrochlorination and the formation of aromatics. FTIR and EDS were used to follow the consumption of the bases present in the chemical removers and the suppression of the $\mathrm{C}-\mathrm{Cl}$ absorption bands of the $\mathrm{PVC}-\mathrm{CHCl}$ - groups during pyrolysis, as well as the formation of the resulting salts $\left(\mathrm{NaCl}, \mathrm{CaCl}_{2}\right.$ and $\left.\mathrm{ZnCl}_{2}\right)$. The chemical removers exhibited chlorine retentions of up to 71 wt. \% (using $\mathrm{Na}_{2} \mathrm{CO}_{3}-\mathrm{ZnO}$ ), while the adsorbents presented a maximum of $19 \%$ of retention at $550{ }^{\circ} \mathrm{C}$ and heating rate of $200^{\circ} \mathrm{C} / \mathrm{min}$.

\footnotetext{
*Corresponding author. E-mail address: Daniel.Torres-Gamarra@cranfield.ac.uk / dtorres@icb.csic.es (D. Torres).
} 
24 Keywords: chlorine removal; PVC dehydrochlorination; PVC pyrolysis; hydrochloric acid removers; thermogravimetric analysis; FTIR

\section{Highlights}

- The behaviour of different HCl-removing materials in PVC pyrolysis is studied

- A powder characterization method to exam chlorinated plastic pyrolysis is developed

- FTIR shows the reactive species use and the PVC C-Cl absorption bands suppression

- EDS and FTIR confirm the chlorine salts formed $\left(\mathrm{NaCl}, \mathrm{CaCl}_{2}\right.$ and $\left.\mathrm{ZnCl}_{2}\right)$ in the chars

- $\mathrm{Na}_{2} \mathrm{CO}_{3}-\mathrm{ZnO}$-based removers exhibited $\mathrm{Cl}$ retentions of up to $71 \mathrm{wt} . \%$ after pyrolysis 
Plastics use, and their growing global demand, is leading to the depletion of non-renewable fossil feedstocks. The lack of readily available suitable recycling methods is also leading to the accumulation of plastic waste causing significant environmental issues [1]. Plastic pyrolysis is gaining interest as an attractive method of recovering chemicals from plastic waste through a process known as feedstock recycling. Pyrolysis can utilise "dirty" plastics which cannot be recycled satisfactorily by other methods such as mechanical recycling. The pyrolysis of mixed waste plastics generates an oil with a high calorific value that is transportable and stored. However, the pyrolysis of waste containing PVC is still a challenge due to the generation of $\mathrm{HCl}$ which corrodes equipment and contaminates the products with organochlorine compounds [2,3]. The thermal decomposition of PVC has been extensively investigated [2-4], and a number of methods explored to generate a product with reduced chlorine content. These include preheating to dechlorinate the plastic waste, the dehydrochlorination of municipal plastic waste containing PVC, or the use of absorbents to capture the $\mathrm{HCl}$ generated in-situ [4implemented with this same objective [6,8-11]. In terms of practicality, the co-pyrolysis of PVC, in the presence of other plastics (PE, PP, PS or PET [12]) or biomass [13], has been investigated with an aim to reduce costs, enhance the pyrolysis of its components, or even dilute the chlorine products obtained [4,14]. In single-step co-pyrolysis, interactions of PVC with other hydrocarbon materials can generate new chlorinated compounds in addition to those from the PVC [4]. These interactions between different kinds of plastics were studied by many authors to establish their kinetics $[15,16]$. In stepwise pyrolysis, a dehydrochlorination step at temperatures below $350{ }^{\circ} \mathrm{C}$ is either carried out before the pyrolysis at high temperature (up to $800^{\circ} \mathrm{C}$ ) or involves the use of catalysts [7- 
temperature and pressure or the necessity of catalysts $[8,20]$. In this case, the co-pyrolysis comprising PS and polyolefinic plastics [8,12] or biomass [13] did not affect the PVC dehydrochlorination. In addition, hemicellulose is a sustainable chlorine adsorbent that has shown to reduce the $\mathrm{HCl}$ emissions when lignocellulose is included in the PVC pyrolysis [19], but can lead to a high acidic oil.

Catalysts or catalytic adsorbents in the pyrolysis of PVC or chlorinated waste have been employed. These include solid catalysts such as zeolites, FCC, mesoporous silica, $\mathrm{Al}(\mathrm{OH})_{3}$, $\mathrm{MoO}_{3}, \mathrm{Al}-\mathrm{Zn}$ composite, $\mathrm{Ni}-\mathrm{Ca}$ - and iron oxide-based catalysts which have shown to reduce chlorine content in the liquid products $[10,14,17,18,20-28]$. If the dechlorination of the pyrolysis oil is considered, catalytic or high-pressure hydrogenation routes simultaneously deal with condensed $\mathrm{HCl}$ and organochlorine compounds [5,29]. On the other hand, dry scrubbing of pyrolysis exhaust gases or the use of hot filters and additives (in or ex-situ) are also alternatives explored for $\mathrm{HCl}$ conversion and the upgrading (quality or distribution) of the pyrolysis products. Those investigated include Ca-based adsorbents $\left(\mathrm{Ca}(\mathrm{OH})_{2}, \mathrm{CaO}, \mathrm{CaCO}_{3}\right.$, lime), Na-based adsorbents $\left(\mathrm{NaHCO}_{3}, \mathrm{Na}_{2} \mathrm{CO}_{3}\right)$, metal oxides $\left(\mathrm{MgO}, \mathrm{Al}_{2} \mathrm{O}_{3}, \mathrm{SiO}_{2}, \mathrm{PbO}, \mathrm{ZnO}\right.$, $\mathrm{FeO}, \mathrm{Fe}_{2} \mathrm{O}_{3}$, red mud) and lanthanide oxides $\left(\mathrm{La}_{2} \mathrm{O}_{3}, \mathrm{Nd}_{2} \mathrm{O}_{3}, \mathrm{CeO}_{2}\right)[7,9,13,17,23,24,27,29-42]$. In this work, a comprehensive powder characterization method was developed to screen the ability of a range of chemicals and absorbents to retain chlorine from the pyrolysis of chlorinated plastics. The behaviour of six different materials for the removal of hydrochloric acid released during the PVC pyrolysis was studied. Solid chlorine removers, including different adsorbents and chlorine scrubbers, were mixed with PVC $(1: 1 ;$ wt./wt. $)$ and pyrolyzed in a thermobalance at $550{ }^{\circ} \mathrm{C}$ until complete dehydrochlorination of PVC occurred. The resulting chars were analysed by Fourier transform infrared spectroscopy (FTIR), CHN elemental analysis and scanning electron microscopy-energy dispersive X-ray spectroscopy (ESEM-EDS). This is the first time that solid characterization techniques (TGA, FTIR and 
ESEM-EDS) are used in a complementary way to compare the behaviour offered by the materials in the PVC dehydrochlorination process. Conventionally, the $\mathrm{HCl}$ present in the evolved gases released during the pyrolysis is measured by coupled TGA-spectroscopic techniques, such as FTIR. This new procedure is presented as a practical method, consuming just milligrams of the sample, to screen the ability of materials for use as $\mathrm{HCl}$ removers in the pyrolysis of PVC.

\section{MATERIALS AND METHODS}

\subsection{Materials}

Pure polyvinyl chloride, without additives or plasticisers, (Sigma Aldrich, purity $>99 \%$ ) was used as received. Two classes of chlorine removers were characterized and used. The first class were three chemical removers (that involved a chemical reaction during the process) based on $\mathrm{NaHCO}_{3}, \mathrm{CaO}$ and $\mathrm{Na}_{2} \mathrm{CO}_{3}-\mathrm{ZnO}$, and the second class were three adsorbents based on $\mathrm{Al}_{2} \mathrm{O}_{3}$ and $\mathrm{NaX}$ zeolites. Table 1 lists the elemental composition of these materials, which are labelled as Chem- $\mathrm{NaHCO}_{3}$, Chem-CaO, Chem- $\mathrm{Na}_{2} \mathrm{CO}_{3}-\mathrm{ZnO}$, Ads- $\mathrm{Al}_{2} \mathrm{O}_{3}-1$, Ads- $\mathrm{Al}_{2} \mathrm{O}_{3}-2$ and Ads$\mathrm{NaX}$. Chem- $\mathrm{NaHCO}_{3}$ and $\mathrm{Chem}-\mathrm{CaO}$ contain a low percentage of carbon as a dilutor of the active phase while Chem- $\mathrm{Na}_{2} \mathrm{CO}_{3}-\mathrm{ZnO}\left(1: 1\right.$, wt./wt.) has a 30 wt. $\% \mathrm{SiO}_{2}-\mathrm{Al}_{2} \mathrm{O}_{3}$ as a support. Ads- $\mathrm{Al}_{2} \mathrm{O}_{3}-1$ and $\mathrm{Ads}-\mathrm{Al}_{2} \mathrm{O}_{3}-2$ correspond to $\mathrm{NaOH}$ activated $\mathrm{Al}_{2} \mathrm{O}_{3}$ at low and high temperatures, respectively. In the case of mixtures, pure PVC and chlorine removers were physically mixed in a ratio of 1:1 (by weight).

Table 1 Elemental composition by EDS and CHN elemental analysis of chemical removers and adsorbents.

\begin{tabular}{cc|c|c|c|c|c|c}
\hline & & Chem-NaHCO $_{3}$ & Chem-CaO & Chem-Na $_{2} \mathbf{C O}_{3}-\mathbf{Z n O}$ & Ads- $_{2} \mathbf{O}_{3}-\mathbf{1}$ & Ads-Al $_{2} \mathbf{O}_{3}-\mathbf{2}$ & Ads-NaX \\
\hline EDS & $\mathbf{C}$ & 20.05 & 9.90 & 2.19 & 0.00 & 0.00 & 0.00 \\
(wt. \%) & $\mathbf{O}$ & 53.29 & 26.03 & 37.47 & 50.51 & 50.01 & 56.72 \\
\hline
\end{tabular}




\begin{tabular}{|c|c|c|c|c|c|c|c|}
\hline \multicolumn{2}{|r|}{$\mathbf{N a}$} & 24.33 & 0.00 & 8.37 & 5.22 & 5.16 & 11.61 \\
\hline & $\mathbf{C a}$ & 0.00 & 63.52 & 0.60 & 0.00 & 0.00 & 0.29 \\
\hline & Al & 0.96 & 0.00 & 7.70 & 41.58 & 40.98 & 12.99 \\
\hline & Zn & 0.00 & 0.00 & 38.30 & 0.00 & 0.00 & 0.00 \\
\hline & $\mathbf{S i}$ & 0.00 & 0.00 & 2.17 & 0.00 & 0.00 & 16.69 \\
\hline & Mg & 0.00 & 0.00 & 0.83 & 0.00 & 0.00 & 0.83 \\
\hline & $\mathbf{F e}$ & 0.00 & 0.00 & 0.31 & 0.00 & 0.00 & 0.39 \\
\hline & Others & 1.38 & 0.55 & 2.07 & 2.70 & 3.85 & 0.48 \\
\hline & $\mathbf{C}$ & 21.63 & 10.64 & 4.19 & 1.21 & 1.66 & 0.20 \\
\hline CHN & H & 1.25 & 2.37 & 1.13 & 1.66 & 1.74 & 2.59 \\
\hline (wt. \%) & $\mathbf{N}$ & 0.08 & 0.09 & 0.00 & 0.00 & 0.01 & 0.01 \\
\hline & Others & 77.04 & 86.90 & 94.68 & 97.13 & 96.59 & 97.20 \\
\hline & $\mathbf{H}_{2} \mathbf{O}^{\mathbf{a}}$ & 1.59 & 3.01 & 7.48 & 7.72 & 8.05 & 15.38 \\
\hline
\end{tabular}

99

100

101

102

103

104

105

106

107

108

109

110

\subsection{Thermobalance tests}

The samples were prepared by grinding in a pestle and mortar and mixed to give the desired compositions. Thermogravimetric analyses were carried out in a Perkin Elmer TGA $8000^{\mathrm{TM}}$ thermogravimetric analyser. TGA profiles were obtained from a sample amount of $20 \pm 5 \mathrm{mg}$ and using $40 \mathrm{ml} \mathrm{min}{ }^{-1}$ of $\mathrm{N}_{2}$ as an inert atmosphere for pyrolysis. The temperature program consisted of rapid heating of the sample $\left(20\right.$ or $\left.200{ }^{\circ} \mathrm{C} / \mathrm{min}\right)$ from room temperature to $550{ }^{\circ} \mathrm{C}$ and a stabilization stage at this temperature for $20 \mathrm{~min} .3$ repetitions were performed for each material or mixture to obtain reproducible results. An average mass loss curve ("Average" in the corresponding TGA and DTG figures) was produced by taking the weighted average of the mass loss of pure PVC and the chemical remover/absorbent materials as follows:

$M_{\text {Average_T }}(g)=\left(M_{P V C_{-} T}+M_{\text {Remover_T }_{-}}\right) / 2$

Equation 1

Where $M_{\text {Average } T}$ is the average mass at a temperature $T$, and $M_{P V C_{-} T}$ and $M_{\text {Remover }_{-}}$are the masses of PVC and the chlorine remover at that temperature $T$. For this calculation, the curves of mass evolution of the PVC and the remover were obtained separately. 


\subsection{Characterization of thermobalance chars}

117 Morphological assessment of the thermobalance chars was performed by environmental scanning electron microscopy (ESEM, FEI Philips XL30) by examining the surface using a back-scattered electrons detector. Coupled to the ESEM, an EDS analyser (Oxford Instruments, X-Max detector) was used to study the chemical composition of the samples. Additionally, EDS accuracy was adjusted for an adequate elemental quantification by determination and subtraction of the contribution of the conductive tab used, measurement of different large areas (at least 5 from 400 to $10,000 \mu \mathrm{m}^{2}$ ) of each sample, correction with data of the CHN elemental analysis and verification with standards of known composition.

The chlorine retention obtained by a remover in the PVC pyrolysis ( $C l$ retention) was calculated as the percentage of chlorine content loss between that calculated in the char and that in the virgin PVC:

Where $M_{C l-P V C}$ and $M_{C l}$ Char correspond to the masses of $\mathrm{Cl}$ in the $\mathrm{PVC}$ and the char, respectively. Both $\mathrm{Cl}$ masses depend on the mass of mixture (PVC + chlorine remover) loaded in the thermobalance.

The FTIR transmittance spectrum for each sample was determined using a SHIMADZU $\mathrm{cm}^{-1}$ and $4000 \mathrm{~cm}^{-1}$. The number of scans and scan resolution were set at 15 and $4 \mathrm{~cm}^{-1}$, respectively.

$136 \mathrm{CHN}$ elemental analysis was performed using a Perkin-Elmer CHN Elemental Analyzer.

Samples were combusted at $900{ }^{\circ} \mathrm{C}$ in an oxygen atmosphere and the combustion gases were passed over a copper catalyst to remove excess $\mathrm{O}_{2}$ and to reduce the $\mathrm{NO}_{\mathrm{x}}$ to elemental nitrogen. 
140 thermal conductivity detector (TCD). For this measurement, TGA chars were dried at $105^{\circ} \mathrm{C}$ 141 for at least $2 \mathrm{~h}$ and $0.020 \mathrm{~g}$ packed in aluminium-foil capsules.

\section{$143 \quad 3$ RESULTS}

\section{$144 \quad 3.1$ Pyrolysis of PVC}

145 Initially, TGA and DTG of PVC (Figure 1) at different heating rates (slow $=20{ }^{\circ} \mathrm{C} / \mathrm{min}$ and 146 fast $=200{ }^{\circ} \mathrm{C} / \mathrm{min}$ ) were performed to see the main mass losses produced during the pyrolysis.

147 As expected for PVC, two main mass losses were observed: the first loss (Zone I), starting at $148 \quad 250-260{ }^{\circ} \mathrm{C}$ is attributed to the release of $\mathrm{HCl}$ and monoaromatics as a result of PVC thermal 149 decomposition, and the second loss (Zone II), starting at $400-450{ }^{\circ} \mathrm{C}$, is due to the degradation 150 of the remaining organic materials [4]. A char-like material remained after the pyrolysis process (7.1-8.7 wt. \%). Although the mass loss attained at the end of Zone I (up to 66.2 wt. \%) comprises the release of the total $\mathrm{HCl}$ content in $\mathrm{PVC}(58.4$ wt. \%) along with the release of mainly benzene and toluene among other aromatics [43], the presence of chlorine derivatives

154 in the char cannot be entirely discounted. In addition to the aromatic hydrocarbons (such as benzene, toluene, naphthalene, o-xylene, etc.) released in Zone I [15], aromatics are generated in higher amounts in Zone II, where condensation and de-alkylation reactions take place [2].

157 On the other hand, chlorinated aromatic hydrocarbon (mainly chlorobenzene) evolution has been detected at higher temperatures (Zone II) [3]. 

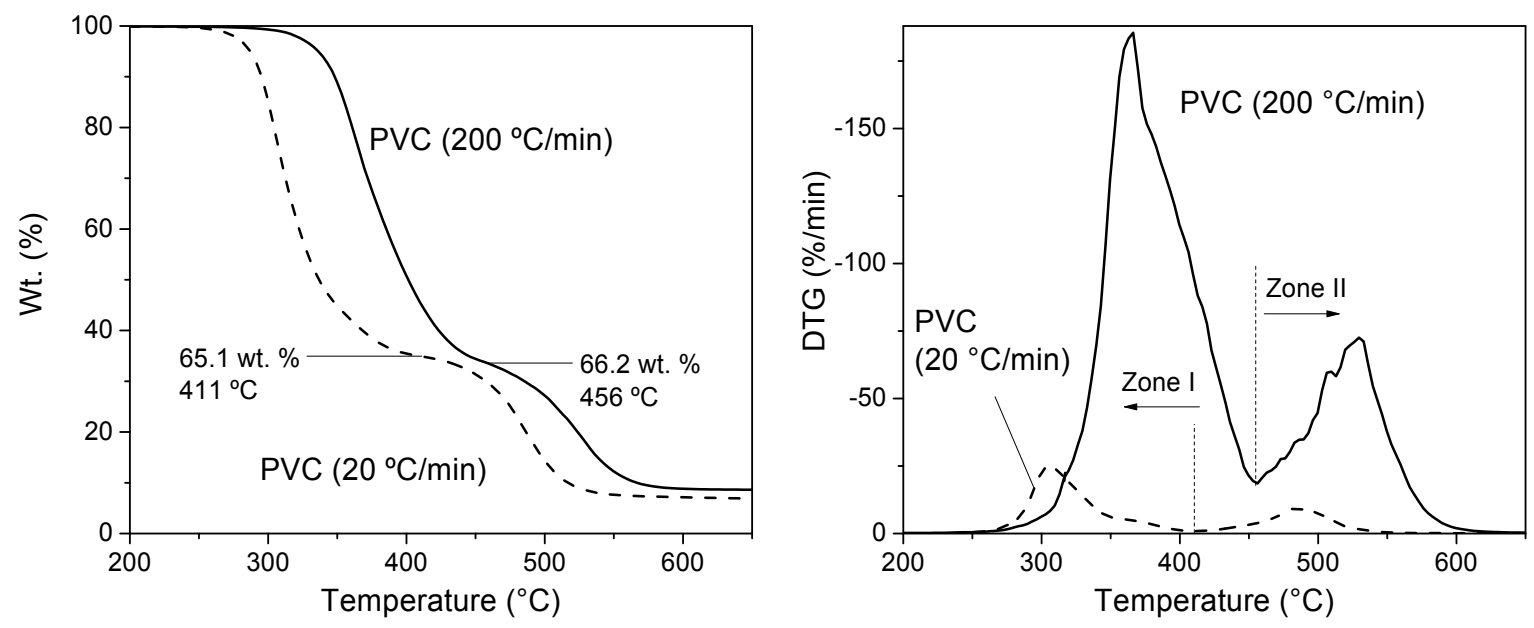

Figure 1 a) TGA and b) DTG profiles of pure PVC using $\mathrm{N}_{2}$ at heating rates of 20 and 200

${ }^{\circ} \mathrm{C} / \mathrm{min}$.

At a heating rate of $200{ }^{\circ} \mathrm{C} / \mathrm{min}$, the first mass loss ends when the temperature exceeds 450 -

$480{ }^{\circ} \mathrm{C}$. The char generated was collected and analysed by FTIR (Figure 2) to see the chemical changes obtained in the char and to follow the variation in the $\mathrm{C}-\mathrm{Cl}$ bond signals. Zhou et al. [44] showed that at $450{ }^{\circ} \mathrm{C}$, near-complete dehydrochlorination of the PVC is achieved, with a $\mathrm{Cl}$ content in the char typically below 1 wt. \%.

The spectra of PVC before and after pyrolysis can give an idea of the dehydrochlorination mechanism $[44,45]$. The spectra shown in Figure 2 were similar to those previously reported for PVC and pyrolyzed PVC, and they were interpreted according to their assignments [44-50]. Despite these similarities (discussed below), both profiles showed differences in the intensities of some peaks concerning those reported, and their analysis serves as a starting point for when comparing the effectiveness of a chlorine remover. Adsorption bands above $2750 \mathrm{~cm}^{-1}$ in PVC and pyrolyzed $\mathrm{PVC}$ are due to $\mathrm{C}-\mathrm{H}$ stretching vibration in $-\mathrm{CH}=\mathrm{CH}-\left(3020 \mathrm{~cm}^{-1}\right),-\mathrm{CH}_{2}-$ (2846, 2855, 2911 and $\left.2920 \mathrm{~cm}^{-1}\right)$ and $-\mathrm{CHCl}-\left(2816\right.$ and $\left.2968 \mathrm{~cm}^{-1}\right)$ functional groups $[44,46]$. Bands associated with the $-\mathrm{CHCl}-$ groups disappeared clearly after pyrolysis, while those of $-\mathrm{CH}=\mathrm{CH}-$ increased, clearly indicating that the dehydrochlorination generated $\mathrm{C}=\mathrm{C}$ 
bonds. Likewise, post pyrolysis, the bands associated with chlorine-free molecules were more prominent. For example, the methylene group peaks $\left(-\mathrm{CH}_{2}-\right)$ shifted from 2911 and $2846 \mathrm{~cm}^{-}$ ${ }^{1}$ to 2920 and $2855 \mathrm{~cm}^{-1}$, respectively [44]. These displacements would be motivated by the different nature of these functional groups: methylene in the original PVC and the aromatic network present in dehydrochlorinated PVC as a result of the transformation of conjugated double bonds [44]. Absorption bands in the range $1800-1000 \mathrm{~cm}^{-1}$ mainly correspond to vibrations of double bonds stretching and of $\mathrm{C}-\mathrm{H}$ deformation. Pyrolyzed $\mathrm{PVC}$ presented a new large band at $1599 \mathrm{~cm}^{-1}$ which was assigned to $\mathrm{C}=\mathrm{C}$ stretching in conjugated $-\mathrm{C}=\mathrm{C}-$ bonds, for both aliphatic and aromatic compounds [47,48]. As in the case of the $2911 \mathrm{~cm}^{-1}$ band, the band at $1425 \mathrm{~cm}^{-1}$, associated with the $\mathrm{C}-\mathrm{H}$ bending in $-\mathrm{CH}_{2}-$ groups, shifted to 1441 $\mathrm{cm}^{-1}$ due to the formation of new methylene groups generated during the transformation of conjugated double bonds. Other bands present in the PVC spectrum such as those at $1198 \mathrm{~cm}^{-}$ ${ }^{1}$ and $1094 \mathrm{~cm}^{-1}$, associated with the $\mathrm{C}-\mathrm{H}$ rocking in methylene groups and the PVC skeletal vibration $(\mathrm{Cl}-\mathrm{C}-\mathrm{H})$, respectively, are not present after pyrolysis. Besides, the bands associated with the $\mathrm{C}-\mathrm{H}$ bending in $-\mathrm{CHCl}-$ groups (at 1329 and $1254 \mathrm{~cm}^{-1}$ ) also disappeared. Other bands at 959 and $833 \mathrm{~cm}^{-1}$ related to the $\mathrm{C}-\mathrm{H}$ rocking of $-\mathrm{CH}_{2}-$ in $\mathrm{PVC}$ are not present after pyrolysis. Just as double $\mathrm{C}=\mathrm{C}$ bonds are formed during the pyrolysis, the new bands at 870 , 810,745 and $700 \mathrm{~cm}^{-1}$ are attributed to aromatic products, specifically to the $=\mathrm{C}-\mathrm{H}$ out of plane vibration in aromatic rings $[47,48]$. It has been shown that the intramolecular reactions of cyclization and aromatization start at temperatures around $300{ }^{\circ} \mathrm{C}$ during PVC pyrolysis [44], although above $400{ }^{\circ} \mathrm{C}$ Diels-Alder reactions between conjugated dienes and olefins on different chains could also occur [2].

The original structure of PVC is destroyed after its thermal dehydrochlorination and the char obtained after pyrolysis does not show the $\mathrm{C}-\mathrm{Cl}$ stretching bands in its spectrum (at 685 and $606 \mathrm{~cm}^{-1}$ ). The decrease in $\mathrm{Cl}$ for the sample pyrolyzed at $480{ }^{\circ} \mathrm{C}$ reached $93 \mathrm{wt} . \%$ as shown 
by the $\mathrm{CHN}$ elemental analysis $(\mathrm{C}=90.51$ wt. \%; $\mathrm{H}=5.39$ wt. \%; $\mathrm{N}=0.09$ wt. \%; Difference $=4.02$ wt. \%). However, this value obtained by difference could imply the presence of other elements in addition to $\mathrm{Cl}$ such as $\mathrm{O}$, which was found to be present at 1.9 wt. \% by ESEMEDS. Taking into account the $\mathrm{O}$, the reduction of $\mathrm{Cl}$ obtained would be 96 wt. \%. At temperatures above $450{ }^{\circ} \mathrm{C}$, the $\mathrm{Cl}$ content in the char has been reported to be below $1.05 \mathrm{wt} . \%$ [44]. According to FTIR and CHN analysis data, the PVC pyrolysis occurs through a clear dehydrochlorination process and the formation of aromatic compounds.
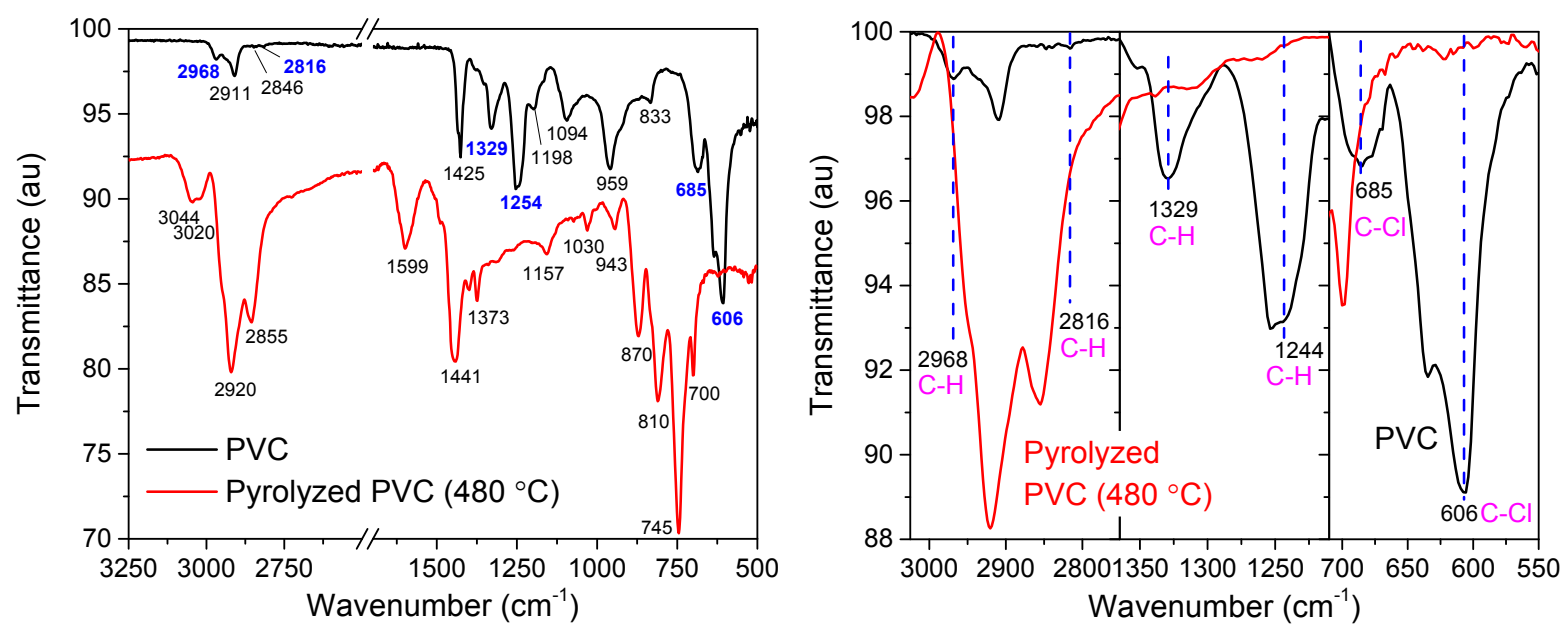

213 Figure 2 a) FTIR spectra of pure PVC and PVC pyrolyzed at $480^{\circ} \mathrm{C}$. b) Zoom of the three zones of bands associated with $\mathrm{C}-\mathrm{H}$ and $\mathrm{C}-\mathrm{Cl}$ stretching in the $-\mathrm{CHCl}-$ groups (shown in blue in a)).

\subsection{Chemical removers and adsorbents behaviour in the PVC pyrolysis}

As a preliminary measurement of chlorine removal, the use of chemical removers and adsorbents were used and in conjunction with the PVC by undertaking pyrolysis in the thermobalance (Figure 3 and Figure 4). Pyrolysis was carried out in an $\mathrm{N}_{2}$ stream up to $550{ }^{\circ} \mathrm{C}$ (with a 20 min isothermal period). This temperature ensures the total dehydrochlorination of the original PVC. Chlorine removers were physically mixed with pure PVC (1:1; by weight). 
Single materials gave mass losses around $10 \mathrm{wt} . \%$ for the studied heating rate $\left(200{ }^{\circ} \mathrm{C} / \mathrm{min}\right)$, except for $\mathrm{Chem}-\mathrm{NaHCO}_{3}(33.1 \% \mathrm{wt}$. loss $)$. This loss was mainly in the $100-225^{\circ} \mathrm{C}$ range and mostly arises from the humidity trapped in the materials in accordance with the EDS and CHN elemental analysis results shown in Table 1. The higher mass loss shown by Chem- $\mathrm{NaHCO}_{3}$ is due to the thermal decomposition of $\mathrm{NaHCO}_{3}$ into $\mathrm{Na}_{2} \mathrm{CO}_{3}, \mathrm{CO}_{2}$ and $\mathrm{H}_{2} \mathrm{O}$.

The presence of a chemical remover/adsorbent in the PVC pyrolysis promoted a measurable variation in the mass loss recorded in Zone I and at the end of the process $\left(550^{\circ} \mathrm{C}\right)$, and suggests a possible indication of chloride retention. An average mass loss curve ("Average" in the figures) was produced by taking the weighted average of the mass loss of pure PVC and the chemical remover/absorbent materials. The difference between the mixed PVC-remover mass loss and the average curve could indicate a possible chemical reaction or physical adsorption of the $\mathrm{HCl}$ gas emitted during the pyrolysis process. Thus, the formation of salts with a molecular weight higher than those of their respective bases after the reaction is expected to be seen by this technique for the chemical removers (see in equations 3 to 5 ). The existence of a chemical reaction (or adsorption process) is more evident when looking at the Zone I of the DTG curves where the PVC dehydrochlorination process occurs. Table 2 summarises the differences in the mass losses for PVC mixed with the different chlorine removers. The compositions of the chemical removers $\mathrm{NaHCO}_{3}\left(\mathrm{Chem}-\mathrm{NaHCO}_{3}\right), \mathrm{CaO}(\mathrm{Chem}-\mathrm{CaO}), \mathrm{ZnO}$ and $\mathrm{Na}_{2} \mathrm{CO}_{3}\left(\mathrm{Chem}-\mathrm{Na}_{2} \mathrm{CO}_{3}-\mathrm{ZnO}\right)$ can react with acidic $\mathrm{HCl}$ gas releasing $\mathrm{H}_{2} \mathrm{O}$ only or $\mathrm{H}_{2} \mathrm{O}$ and $\mathrm{CO}_{2}$ depending on the base used as shown in equations 3 to 5 below. As mentioned before, $\mathrm{NaHCO}_{3}$ in $\mathrm{Chem}-\mathrm{NaHCO}_{3}$ decomposes completely into $\mathrm{Na}_{2} \mathrm{CO}_{3}$ during the process. The formation of $\mathrm{Na}_{2} \mathrm{CO}_{3}$ is completed before the dehydrochlorination of PVC occurs, as is clearly seen in Figure 3, therefore, the reaction between $\mathrm{NaHCO}_{3}$ and the released $\mathrm{HCl}$ does not take place (reaction not included in the equations shown below). The formed salts of $\mathrm{CaCl}_{2}, \mathrm{ZnCl}_{2}$ 
and $\mathrm{NaCl}$ will remain in the char after the pyrolysis, and change the final char mass when compared to that of the average curve, as long as the chemical reaction occurs. The reactions between the bases of the chemical removers and $\mathrm{HCl}$ gas [37,51-53] are given as:

$251 \underline{\text { Chem- } \mathrm{NaHCO}_{3}}$ and $\mathrm{Chem}-\mathrm{Na}_{2} \underline{\mathrm{CO}}_{3} \underline{-}-\mathrm{ZnO}:$

$\mathrm{Na}_{2} \mathrm{CO}_{3}(\mathrm{~s})+2 \mathrm{HCl}(\mathrm{g}) \rightarrow 2 \mathrm{NaCl}(\mathrm{s})+\mathrm{H}_{2} \mathrm{O}(\mathrm{g})+\mathrm{CO}_{2}(\mathrm{~g}) ; \Delta \mathrm{H}^{0}=-142.2 \mathrm{~kJ} / \mathrm{mol}$ Equation 3

$\underline{\text { Chem- } \mathrm{Na}_{2}} \underline{\mathrm{CO}_{3}}-\underline{\mathrm{ZnO}}$ :

Given the difference between the actual and average behaviour of the chlorine removers, some parameters are of interest: the temperature at which dehydrochlorination begins (onset), the temperature of the maximum gas release $\left(T_{\max }\right)$ and the mass loss after Zone I. These parameters are included in Table 2. In all mixtures, the manifestation of a chemical reaction or an adsorption process is noticeable due to the observable changes in Zone I, where smaller but faster weight losses can be observed, which generates a distinguishable peak that concentrates the main release of gas at a temperature $\left(T_{\max }\right)$, as well as the delay of the onset. The most drastic changes occur with the use of chemical removers, Chem- $\mathrm{NaHCO}_{3}$, Chem-CaO and Chem- $\mathrm{Na}_{2} \mathrm{CO}_{3}-\mathrm{ZnO}$, which concentrate the release of gas in Zone I at a temperature close to that of the pyrolysis of PVC alone $\left(372.9^{\circ} \mathrm{C}\right.$, see $T_{\max }$ in Table 2$)$. According to the chemical reactions that can take place, the use of chemical removers causes a release of $\mathrm{H}_{2} \mathrm{O}$ and $\mathrm{CO}_{2}$ produced from the formation of the corresponding chlorine salt. Note, with the use of Chem$\mathrm{CaO}$ the only emission from the reaction of its base is $\mathrm{H}_{2} \mathrm{O}$. The adsorbents showed different behaviours, Ads- $\mathrm{Al}_{2} \mathrm{O}_{3}-1$ and $\mathrm{Ads}-\mathrm{Al}_{2} \mathrm{O}_{3}-2$ gave a low release rate of gas (much lower than in 
the case of chemical removers) at 360 and $358^{\circ} \mathrm{C}$, respectively, while with the use of Ads-NaX this was delayed to $397.5^{\circ} \mathrm{C}$. The chemical removers $\mathrm{Chem}-\mathrm{Na}_{2} \mathrm{CO}_{3}-\mathrm{ZnO}$ and $\mathrm{Chem}-\mathrm{CaO}$ gave mass differences of $-25.5 \%$ and $-24.6 \%$ concerning the theoretical behaviour (see Diff. in

275 Table 2). Among these results, the low mass difference calculated for Chem- $\mathrm{NaHCO}_{3}(-5.5 \%)$

276 stands out, but has also given the highest gas release per mole of remover as seen in DTG (at
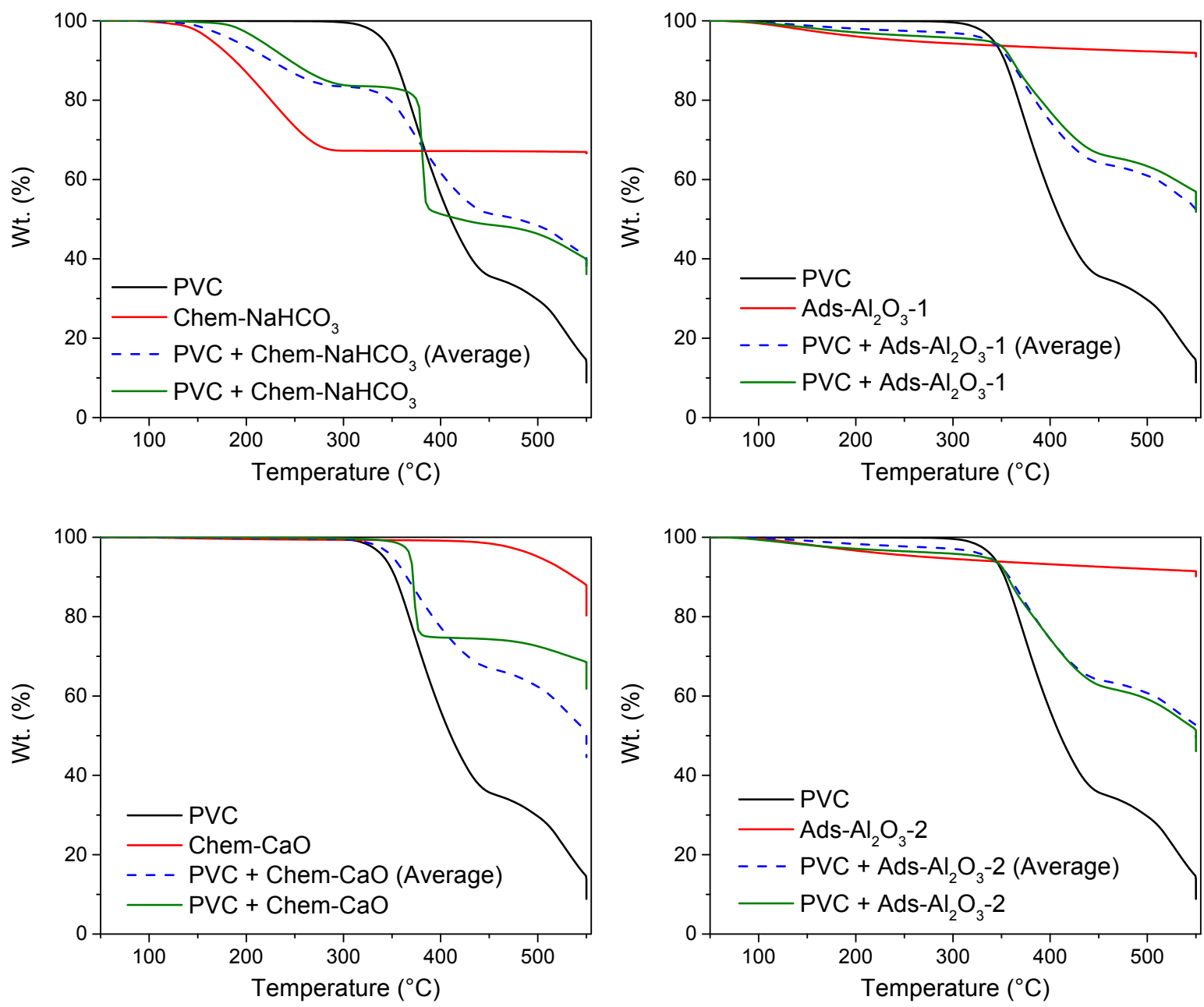

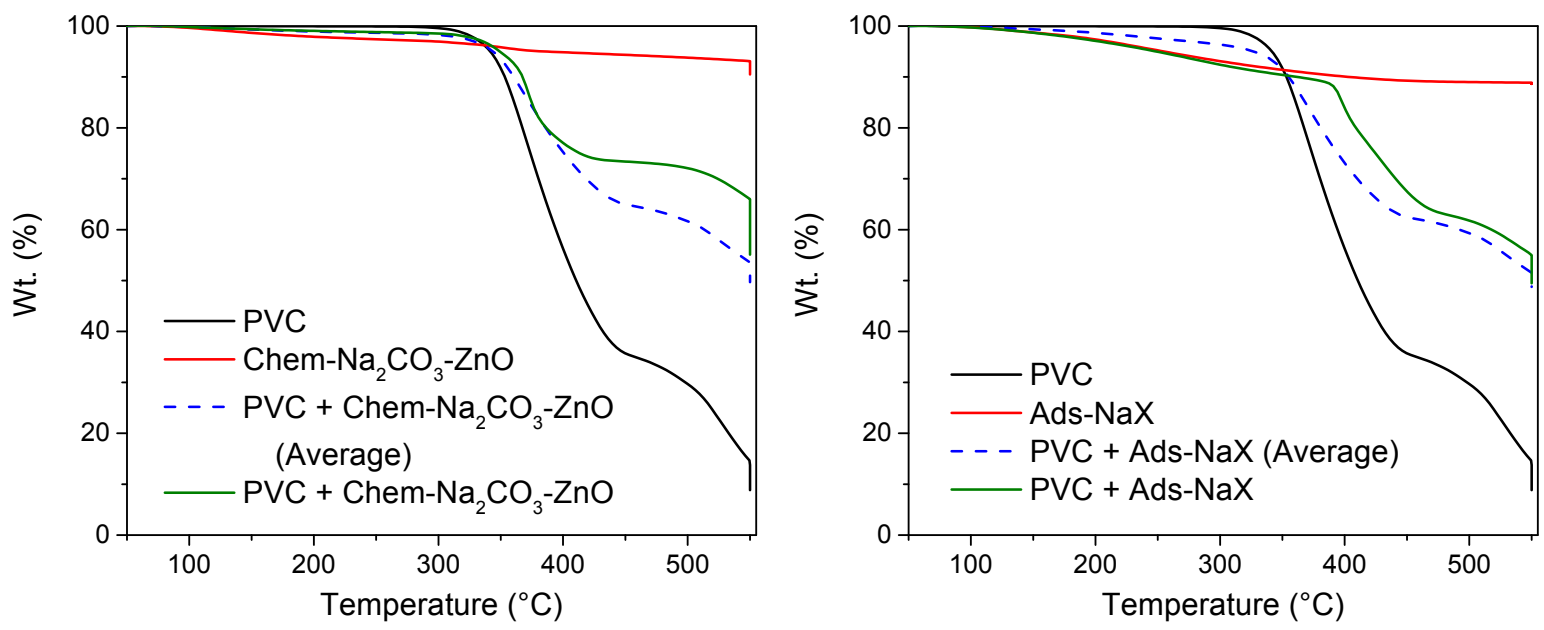

284 Figure 3 TGA curves of PVC and additives (single and mixed). The average curve of the

285 mixture is also included. Heating rate of $200{ }^{\circ} \mathrm{C} / \mathrm{min}$ from room temperature to $550{ }^{\circ} \mathrm{C}$ followed by a hold of $20 \mathrm{~min}$ at this temperature.

287
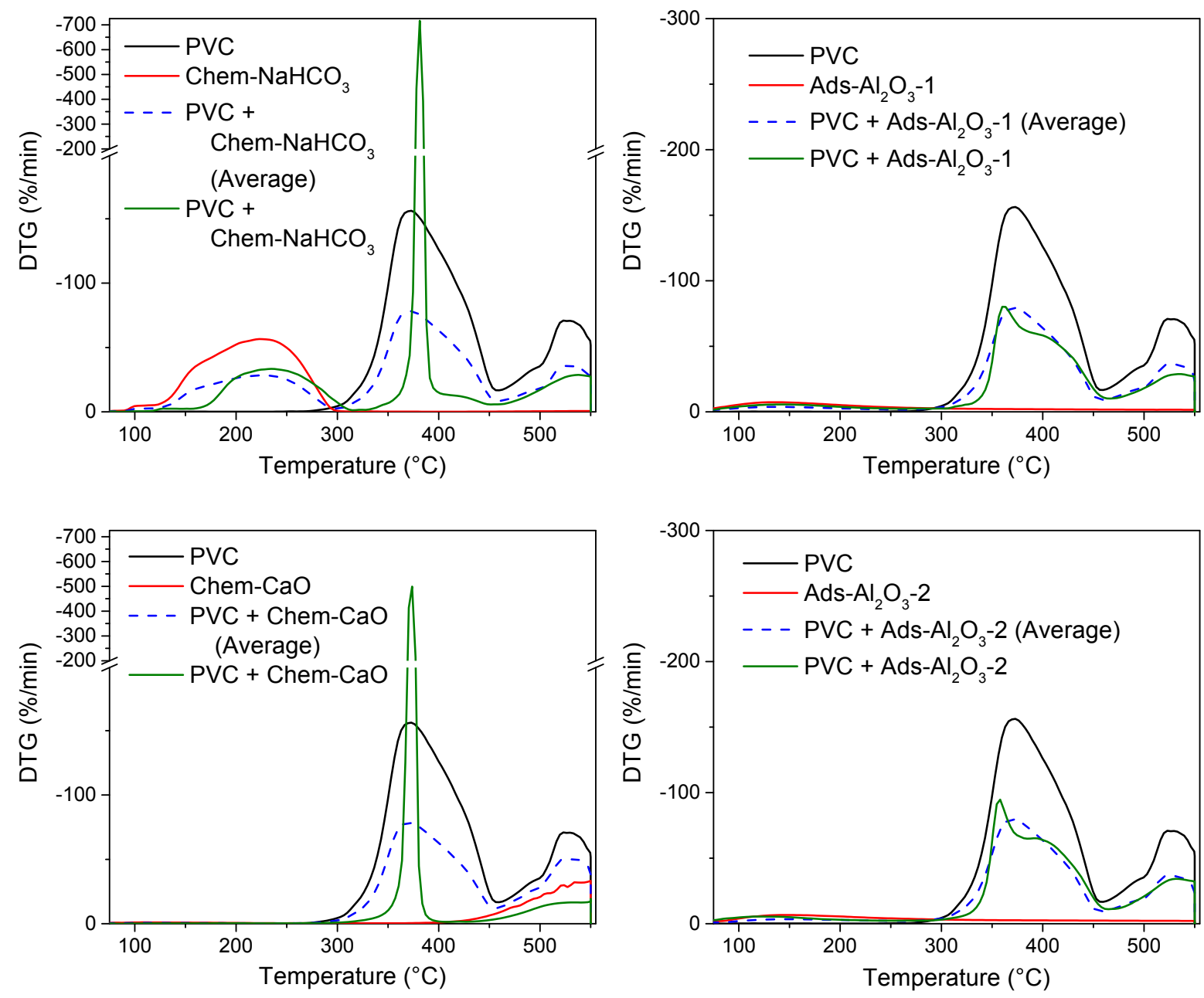

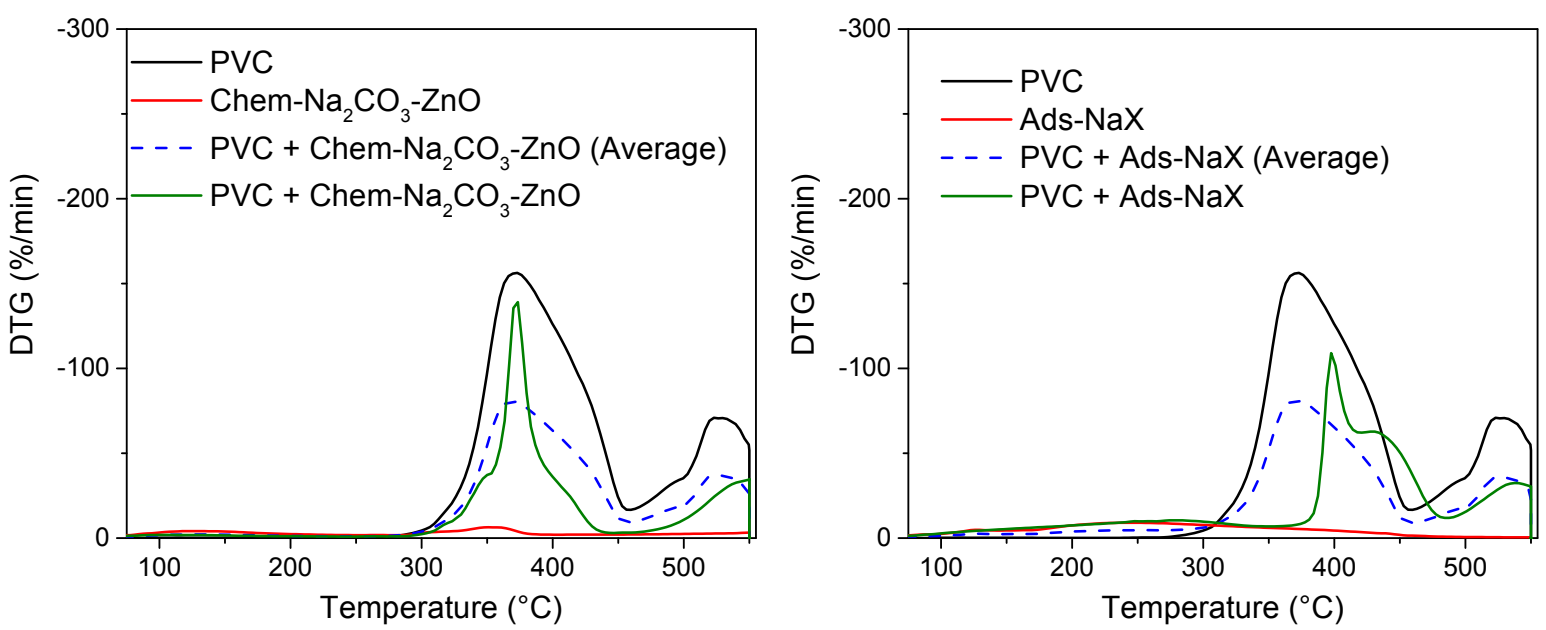

291 Figure 4 DTG curves of PVC and additives (single and mixed). The average curve of the 292 mixture is also included. Heating rate of $200{ }^{\circ} \mathrm{C} / \mathrm{min}$ from room temperature to $550{ }^{\circ} \mathrm{C}$ followed 293 by a hold of 20 min at this temperature.

294

295 Table 2 Weight loss and onset data calculated from TGA and DTG curves of PVC and 296 mixtures.

\begin{tabular}{|c|c|c|c|c|c|c|c|}
\hline Sample & $\begin{array}{l}\text { Zone I } \\
(w t . \%)\end{array}$ & $\begin{array}{c}\text { Zone I }^{a} \\
(w t . \%)\end{array}$ & $\begin{array}{c}\text { Diff. }{ }^{b} \\
(\%)\end{array}$ & $\begin{array}{l}\boldsymbol{T}_{\max } \\
\left({ }^{\circ} \mathrm{C}\right)\end{array}$ & $\begin{array}{c}\text { Onset } \\
\left({ }^{\circ} \mathrm{C}\right)\end{array}$ & $\begin{array}{c}\text { Onset }^{a} \\
\left({ }^{\circ} \mathrm{C}\right)\end{array}$ & $\begin{array}{l}\Delta T^{c} \\
\left({ }^{\circ} \mathrm{C}\right)\end{array}$ \\
\hline PVC & 65.2 & - & - & 372.9 & 340.8 & - & - \\
\hline $\mathrm{PVC}+$ Chem-NaHCO & 30.9 & 32.7 & -5.5 & 381.2 & 399.6 & 342.2 & 57.4 \\
\hline $\mathrm{PVC}+$ Chem-CaO & 25.1 & 33.3 & -24.6 & 373.7 & 367.9 & 340.6 & 27.3 \\
\hline $\mathrm{PVC}+$ Chem- $\mathrm{Na}_{2} \mathrm{CO}_{3}-\mathrm{ZnO}$ & 25.4 & 34.1 & -25.5 & 373.3 & 357.0 & 338.5 & 18.5 \\
\hline $\mathrm{PVC}+\mathbf{A d s}-\mathrm{Al}_{2} \mathrm{O}_{3}-\mathbf{1}$ & 30.6 & 33.7 & -9.2 & 360.0 & 348.8 & 341.3 & 7.5 \\
\hline $\mathrm{PVC}+\mathrm{Ads}-\mathrm{Al}_{2} \mathrm{O}_{3}-2$ & 34.3 & 33.8 & 1.5 & 357.9 & 345.0 & 340.3 & 4.7 \\
\hline PVC + Ads-NaX & 27.7 & 35.1 & -21.1 & 397.5 & 390.5 & 341.9 & 48.6 \\
\hline
\end{tabular}
a: Weight loss calculated from the average curve; $b$ : Weight loss difference $=($ real weight loss - average weight loss) / average weight loss x 100; $\mathrm{c}: \Delta T=$ Onset - Onset ${ }^{\mathrm{a}}(\mathrm{a}=$ average). 


\subsection{Characterization of chars and measurement of chlorine retention}

As in the case of pure PVC (Figure 2), the chars generated from PVC/chlorine remover mixtures after its pyrolysis at $550^{\circ} \mathrm{C}$ were analysed by FTIR to follow the changes in the signals of the $\mathrm{C}-\mathrm{Cl}$ and $\mathrm{C}-\mathrm{H}$ bonds of the $-\mathrm{CHCl}-$ functional groups. The intention was to observe whether dehydrochlorination of PVC is inhibited, as well as to identify bands of new groups or salts including the $\mathrm{Cl}$ released during the process. Figure $5 \mathrm{a}-\mathrm{b}$ and Figure $5 \mathrm{c}-\mathrm{d}$ show the FTIR spectra of chlorine removers and 1:1 mixtures, respectively, before and after pyrolysis at $550{ }^{\circ} \mathrm{C}$ with a 20 min isothermal period. The main bands assigned to PVC and pyrolyzed PVC in section 3.1 are included (as vertical lines) for comparison.

Chlorine removers showed components with very different contributions in the FTIR spectra (see Figure 5a-b). The main bands presented for Chem- $\mathrm{Na}_{2} \mathrm{CO}_{3}-\mathrm{ZnO}$, Chem- $\mathrm{NaHCO}_{3}$ and Chem- $\mathrm{CaO}$ correspond to the adsorption bands of $\mathrm{Na}_{2} \mathrm{CO}_{3}, \mathrm{ZnO}, \gamma-\mathrm{Al}_{2} \mathrm{O}_{3}$ and $\mathrm{SiO}_{2}$ [54-59], $\mathrm{NaHCO}_{3}$ [56], and $\mathrm{CaO}$ [60], respectively. No bands attributable to carbon were observed in Chem- $\mathrm{NaHCO}_{3}$ and Chem-CaO due to its low concentration (around 10 wt. \%) and low transmittance signal. On the other hand, adsorbents showed typical FTIR spectra of $\mathrm{Al}_{2} \mathrm{O}_{3}$ (Ads- $\mathrm{Al}_{2} \mathrm{O}_{3}-1$ and Ads- $\mathrm{Al}_{2} \mathrm{O}_{3}-2$ ) [59] and $\mathrm{NaX}$ zeolites (Ads-NaX) [61-63]. After pyrolysis in the presence of the single chlorine removers, no significant changes in the FTIR spectra were observed. For all cases, except Chem- $\mathrm{NaHCO}_{3}$, in which the complete transformation of $\mathrm{NaHCO}_{3}$ into $\mathrm{Na}_{2} \mathrm{CO}_{3}$ is now confirmed, there was no change to their original FTIR spectra. For Chem- $\mathrm{Na}_{2} \mathrm{CO}_{3}-\mathrm{ZnO}$ and Ads-NaX, a broad transmittance band associated with the asymmetric stretching of $\mathrm{Si}-\mathrm{O}-\mathrm{Si}$ centred at the $930-990 \mathrm{~cm}^{-1}$ region stood out $[63,64]$. In the case of Ads- $\mathrm{NaX}$, this band includes the vibration of $\mathrm{Si}-\mathrm{O}-\mathrm{Al}$ bonds in found zeolites [64].

The 1:1 mixtures (see Figure 5c-d), shows the bands of the pure PVC and the chlorine remover together: main FTIR bands of the PVC (discussed in Section 3.1) are noticeable in all mixtures. However, significant changes in the FTIR spectra of the single materials have been observed 
after the pyrolysis. At first inspection, the $\mathrm{PVC} \mathrm{C}-\mathrm{Cl}$ bond signals are notably absent post pyrolysis evidencing a complete dehydrochlorination of the PVC (see a zoom of the 775-500 $\mathrm{cm}^{-1}$ region in Figure 6). The chemical removers showed the disappearance of the bands relative to their bases $\left(\mathrm{Na}_{2} \mathrm{CO}_{3}, \mathrm{ZnO}\right.$, and $\left.\mathrm{CaO}\right)$, which were present when they were pyrolyzed without the presence of PVC, and the formation of their respective chlorinated salts. Although all the chemical removers had an excess of base, only Chem-CaO showed the presence of the initial base that could still react with more $\mathrm{HCl}$. Likewise, vibrations of the $\mathrm{Ca}-\mathrm{Cl}$ and $\mathrm{Zn}-\mathrm{Cl}$ bonds (marked in Figure 5c) from the $\mathrm{CaCl}_{2}$ and $\mathrm{ZnCl}_{2}$ salts were present in chars obtained when Chem-CaO and Chem- $\mathrm{Na}_{2} \mathrm{CO}_{3}-\mathrm{ZnO}$ were used in the PVC pyrolysis. Also, Chem$\mathrm{Na}_{2} \mathrm{CO}_{3}-\mathrm{ZnO}$ presents a band around $610 \mathrm{~cm}^{-1}$ that could be associated with the $\mathrm{Si}-\mathrm{Cl}$ bond vibration due to the formation of condensed $\mathrm{SiCl}_{4}$ [65]. In the case of $\mathrm{NaCl}$, despite observing the consumption of $\mathrm{Na}_{2} \mathrm{CO}_{3}$ in Chem- $\mathrm{NaHCO}_{3}$ and $\mathrm{Chem}-\mathrm{Na}_{2} \mathrm{CO}_{3}-\mathrm{ZnO}$, its formation in FTIR profiles is imperceptible because this salt absorbs infrared light outside the $4000-500 \mathrm{~cm}^{-1}$ FTIR region. However, the presence of $\mathrm{NaCl}$ salt in the chars, as well as those of $\mathrm{CaCl}_{2}$ and $\mathrm{ZnCl}_{2}$, are confirmed by EDS (see explanation below). On the other hand, it is difficult to observe adsorption processes that may take place on the materials using FTIR, without considering that the pyrolysis temperatures could cause desorption of the $\mathrm{HCl}$ adsorbed during the process. In this regard, $\mathrm{Al}_{2} \mathrm{O}_{3}$ as adsorbent for $\mathrm{HCl}$ could desorb in the range $27-377{ }^{\circ} \mathrm{C}$ [66]. Likewise, zeolites $\mathrm{X}$ showed good $\mathrm{HCl}$ adsorption at room temperature [67], resulting in its complete desorption at $450{ }^{\circ} \mathrm{C}$ [68]. The transformation observed in the adsorbents is therefore minor and is mainly due to the thermal transformation of their constituents. However, Ads-NaX showed recognizable signals of PVC pyrolysis products, specifically those bands attributed to the $=\mathrm{C}-\mathrm{H}$ vibration of aromatic compounds (at 870, 810, 745 and $\left.700 \mathrm{~cm}^{-1},[47,48]\right)$. Likewise, these bands are the most evident in the samples, mainly for Chem- $\mathrm{NaHCO}$, Chem- $\mathrm{Na}_{2} \mathrm{CO}_{3}$ $\mathrm{ZnO}$ and Ads-NaX. 

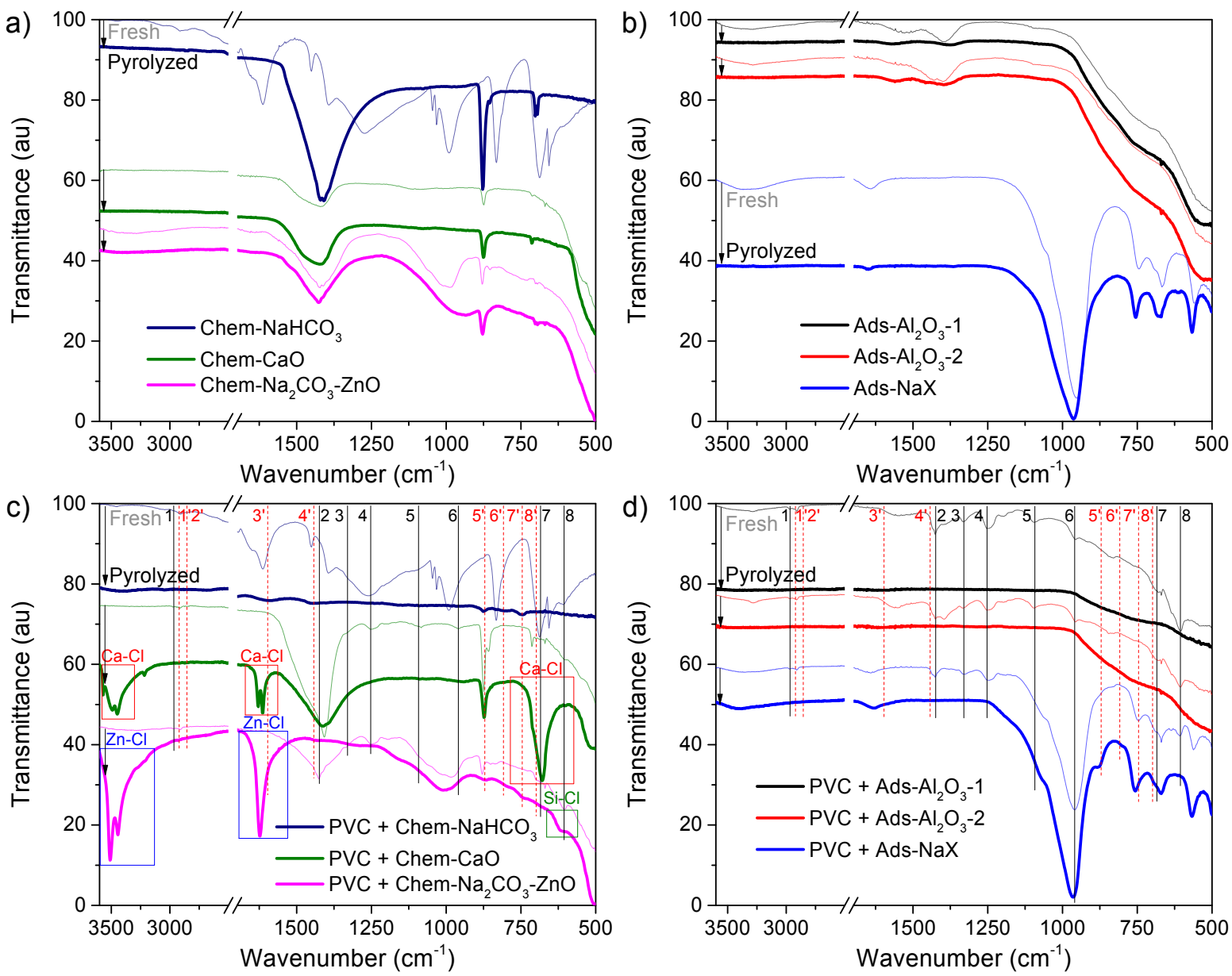

Figure 51 FTIR spectra of fresh and $550^{\circ} \mathrm{C}$-pyrolyzed a) chemical removers and b) adsorbents, and FTIR spectra of mixtures of c) chemical removers and d) adsorbents with PVC. PVC Bands

355 (black solid lines; data from Figure 2): $1=2968,2=1425,3=1329,4=1254,5=1094,6=$ $356959,7=685$ and $8=606 \mathrm{~cm}^{-1}$. Pyrolyzed PVC Bands (red dashed lines; data from Figure 2): $1^{\prime}=2920,2^{\prime}=2855,3^{\prime}=1599,4^{\prime}=1441,5^{\prime}=870,6^{\prime}=810,7^{\prime}=745$ and $8^{\prime}=700 \mathrm{~cm}^{-1}$. 

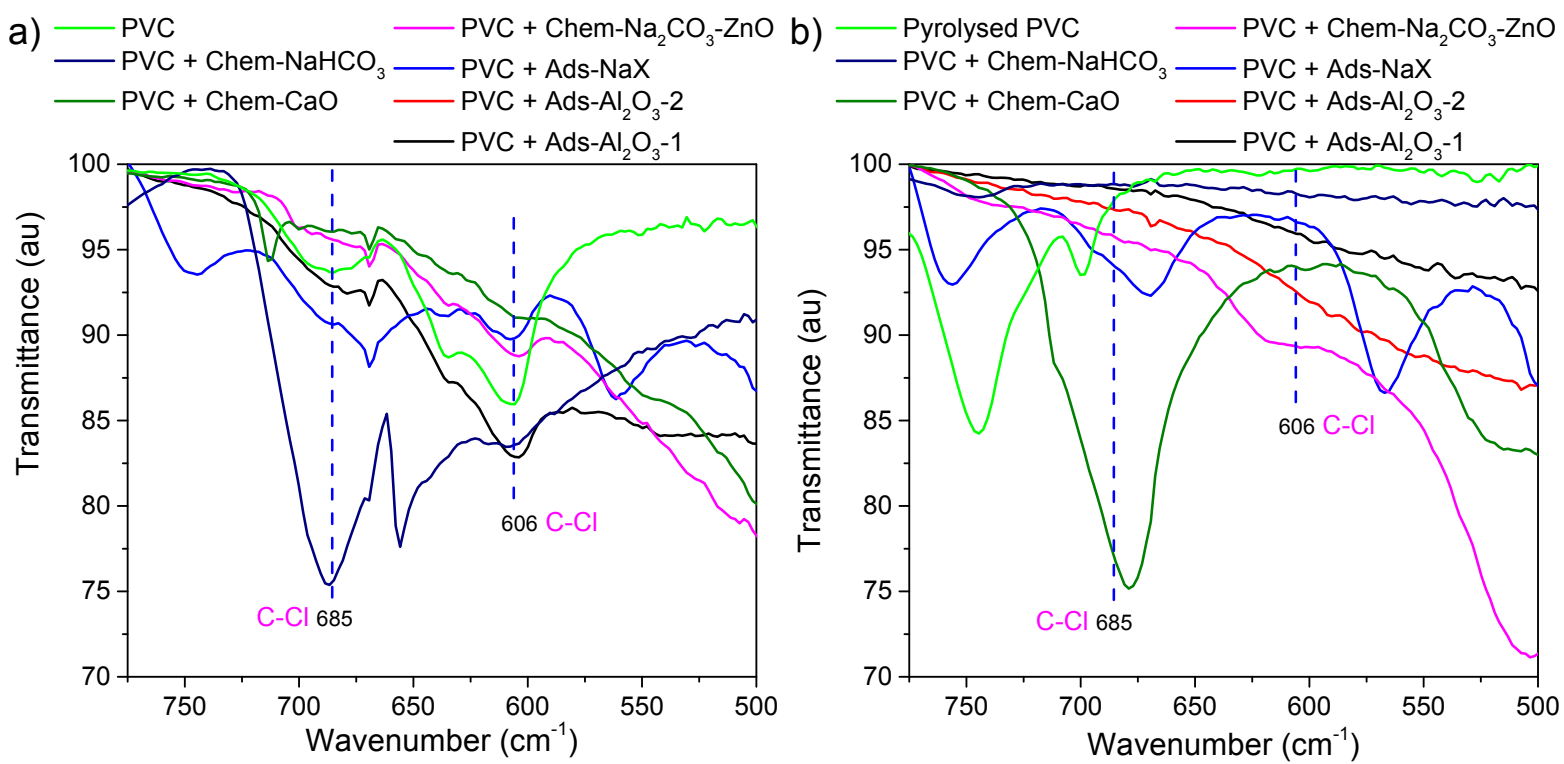

360 Figure 6 Zoom of the FTIR $775-500 \mathrm{~cm}^{-1}$ region (from Figure 5c and Figure 5d) in a) fresh

and b) pyrolyzed mixtures. Dashed lines correspond to the theoretical position of the bands associated with $\mathrm{C}-\mathrm{Cl}$ stretching in the $-\mathrm{CHCl}-$ groups.

364 A morphological and chemical study of the chlorine removers before and after their use in the PVC pyrolysis was undertaken by ESEM-EDS. Micrographs of starting materials can be found in Figure 7. The carbon, easily distinguishable in the images of Chem-CaO and Chem- $\mathrm{NaHCO}$ (Figure 7a and 7b), is completely separated from the bases. The image of Ads-NaX (Figure 7f) stands out as it shows spheres of a few micrometres corresponding to NaX zeolites [61].

a)

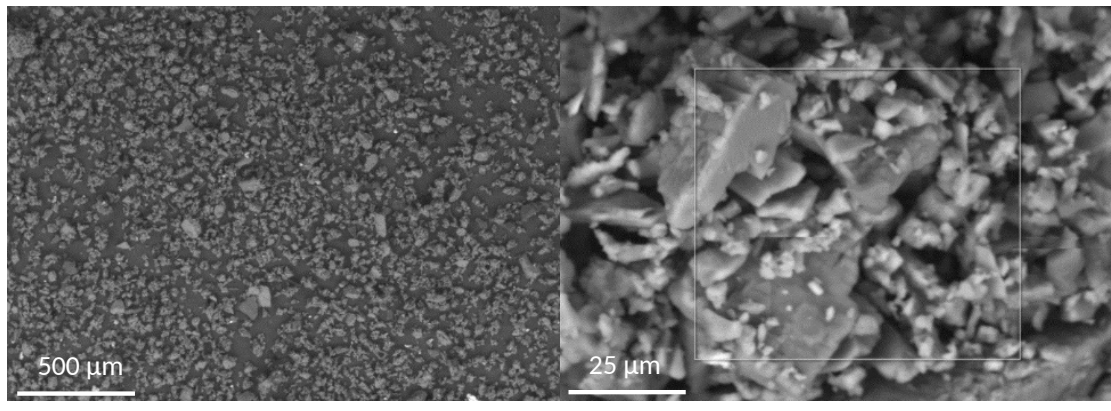


b)

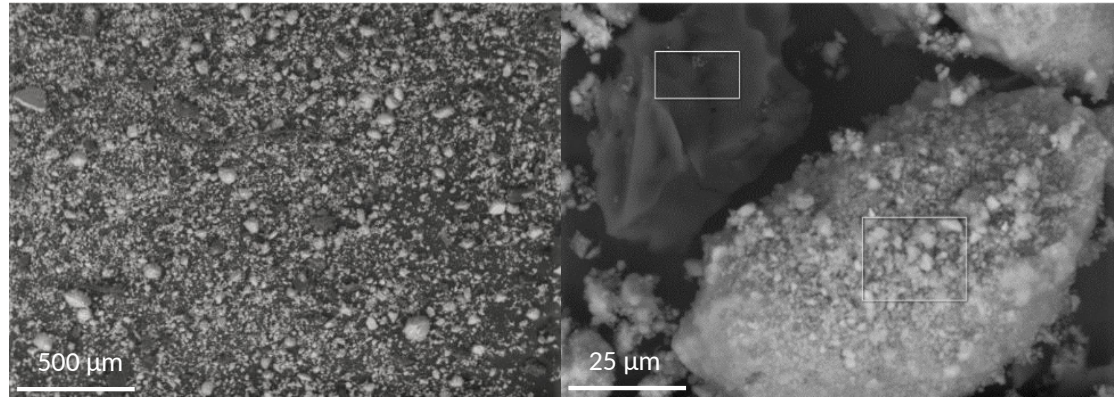

c)
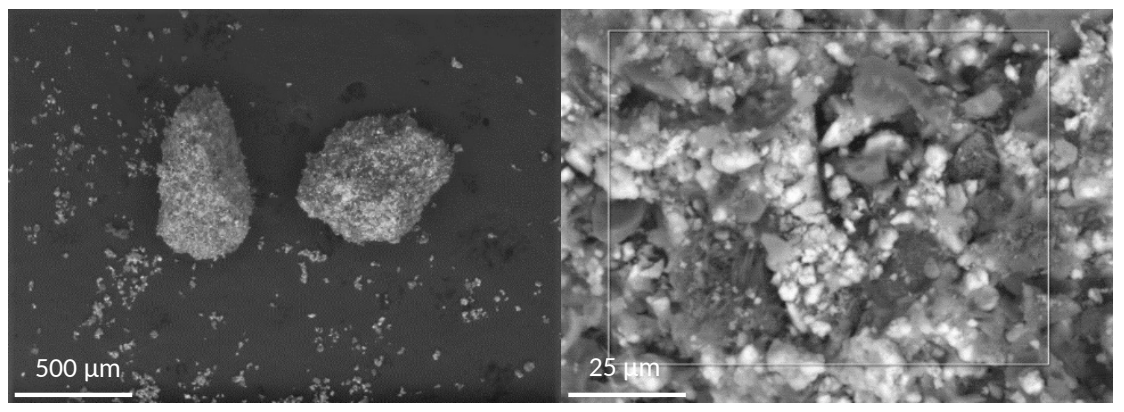

d)
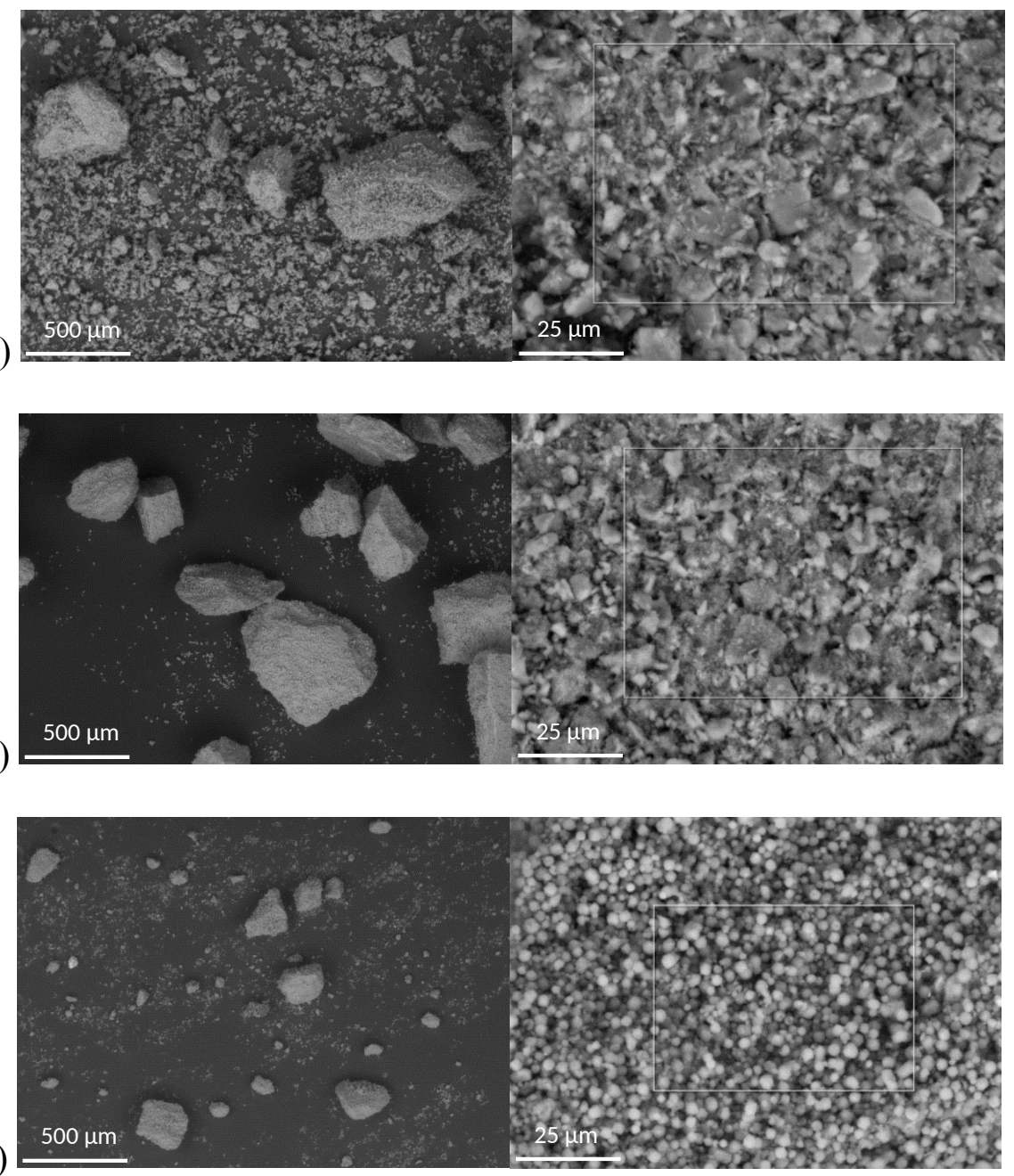
Figure 7 ESEM images of a) Chem- $\mathrm{NaHCO}_{3}$; b) Chem-CaO; c) Chem- $\mathrm{Na}_{2} \mathrm{CO}_{3}-\mathrm{ZnO}$; d) Ads$\mathrm{Al}_{2} \mathrm{O}_{3}-1$; e) Ads- $\mathrm{Al}_{2} \mathrm{O}_{3}-2$; and f) Ads-NaX chlorine removers. High magnification ESEM images show examples of rectangular areas used for the chlorine determination by EDS.

379

380 After the pyrolysis tests using mixtures of PVC, chars obtained from adsorbent containing mixtures showed a similar morphology to those of the starting materials as any changes were difficult to see due to the low proportion (5 wt.\%) of char present. However, the chemical removers showed significant changes in their morphology, especially in the case of Chem$\mathrm{CaO}$, due to the formation of chlorine salts (confirmed by EDS) and particle agglomeration, and their images are presented in Figure 8 below.

a)

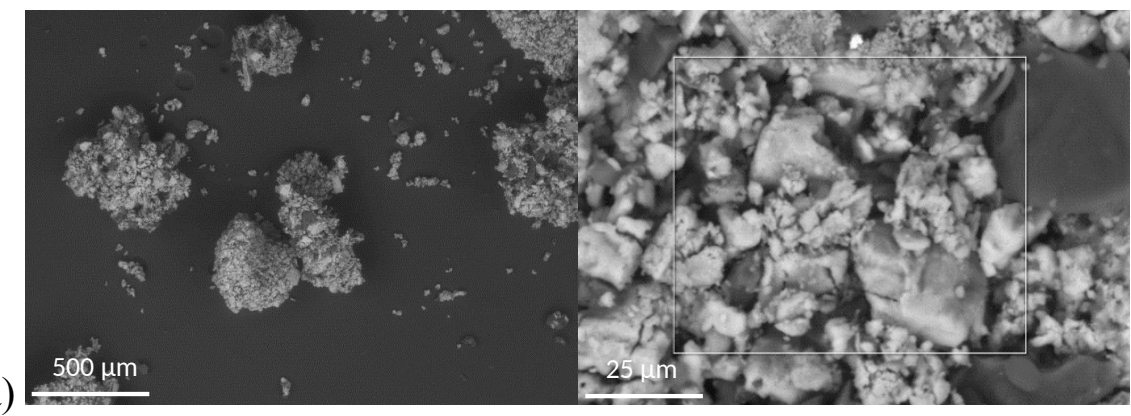

b)
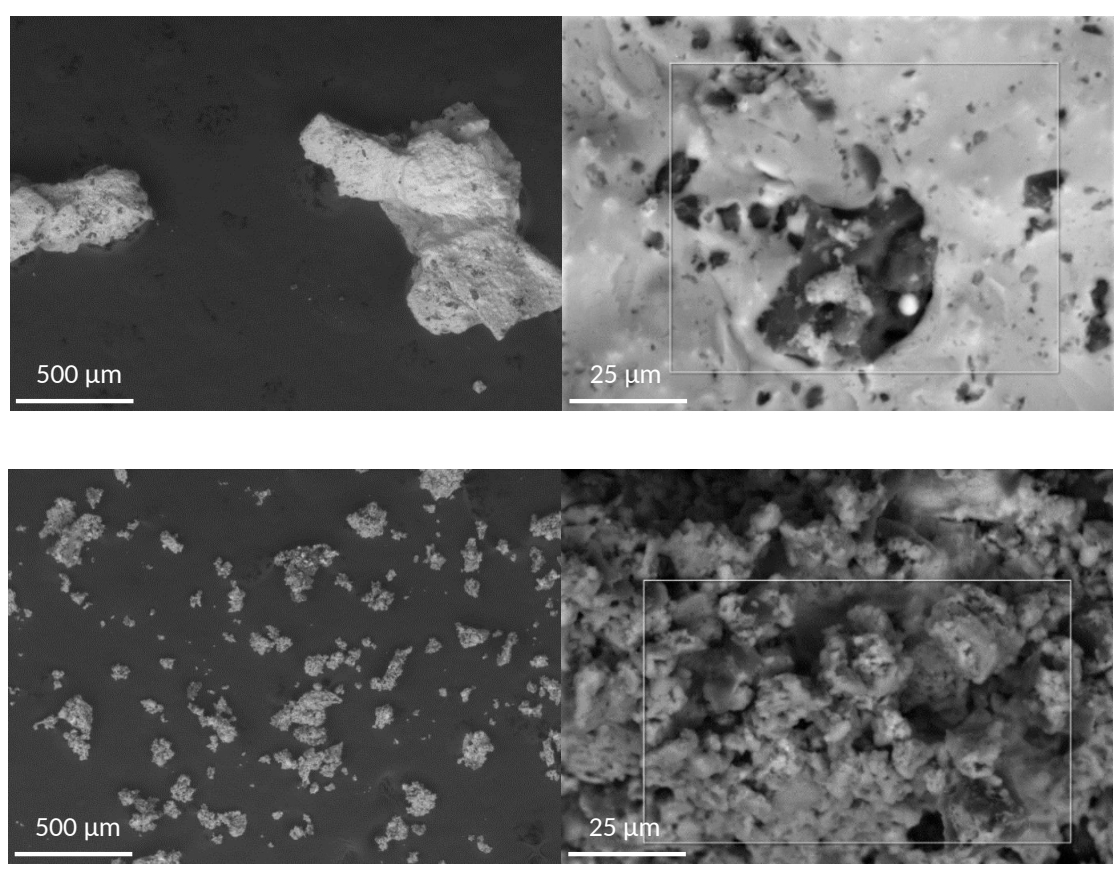
Figure 8 ESEM images of a) $\mathrm{PVC}+\mathrm{Chem}-\mathrm{NaHCO}_{3}$; b) $\mathrm{PVC}+\mathrm{Chem}-\mathrm{CaO}$; and c) $\mathrm{PVC}+$ Chem- $\mathrm{Na}_{2} \mathrm{CO}_{3}-\mathrm{ZnO}$ mixtures after pyrolysis in TGA at $550{ }^{\circ} \mathrm{C}$. High magnification ESEM images show examples of rectangular areas used in the chlorine determination by EDS.

The composition of selected chars was determined by EDS to give an average estimation of the chlorine content (5 large areas of each sample were analysed). This measure allows the percentage of $\mathrm{Cl}$ retention achieved with each remover to be estimated. In Table 3 the chlorine retention (wt. \%) for the mixtures is given. The initial chlorine content in the starting mixtures is estimated according to the manufacturer's data for pure PVC which is $56.7 \mathrm{wt}$. \%. Likewise, $550{ }^{\circ} \mathrm{C}$ pyrolyzed PVC showed a chlorine content of about $0.02 \mathrm{wt} . \%$, which is considered in the calculation of the $\mathrm{Cl}$ retention for the chlorine removers. In accordance with the TGA and DTG curves, Chem-CaO and Chem- $\mathrm{Na}_{2} \mathrm{CO}_{3}-\mathrm{ZnO}$ showed the highest chlorine retention (around 63 and 71 wt. \%, respectively). The chemical removers and adsorbents showed lower onset and $\Delta T$ in the TGA (Table 2) as the chlorine retention was higher. In addition, it should be remembered that Chem-CaO still has the capacity to react with more $\mathrm{HCl}$ according to the results of the FTIR above. In the case of adsorbents, Ads-NaX presented the poorest chlorine 406 retention, although the working conditions studied in the present work (direct contact and 550 $\left.{ }^{\circ} \mathrm{C}\right)$ are not optimal for an adsorption process. Under these conditions, the adsorbent Ads$\mathrm{Al}_{2} \mathrm{O}_{3}-2$ gave the best chlorine retention (19 wt. \%). For the adsorbents, the percentile weight difference measured by the TGA (see Diff. in Table 2) seems to be a valid indicator to follow their behaviours since this parameter decreased as the $\mathrm{Cl}$ retention increased in the chars.

412 Table 3 Chlorine retention measured by EDS of TGA chars obtained in the pyrolysis of PVC at $550{ }^{\circ} \mathrm{C}$ (from $50{ }^{\circ} \mathrm{C}$ at $200{ }^{\circ} \mathrm{C} / \mathrm{min}$ ) using different chlorine removers.

\begin{tabular}{l|l}
\hline Sample & Cl retention (wt. \%) \\
\hline
\end{tabular}




\begin{tabular}{|c|c|}
\hline PVC & $0^{\mathrm{a}}$ \\
\hline $\mathrm{PVC}+\mathrm{Chem}-\mathrm{NaHCO}_{3}$ & 49 \\
\hline PVC + Chem-CaO & 63 \\
\hline $\mathrm{PVC}+\mathrm{Chem}-\mathrm{Na}_{2} \mathrm{CO}_{3}-\mathrm{ZnO}$ & 71 \\
\hline $\mathrm{PVC}+\mathrm{Ads}-\mathrm{Al}_{2} \mathrm{O}_{3}-1$ & 13 \\
\hline $\mathrm{PVC}+\mathrm{Ads}-\mathrm{Al}_{2} \mathrm{O}_{3}-\mathbf{2}$ & 19 \\
\hline PVC + Ads-NaX & 8 \\
\hline
\end{tabular}

415

\section{Conclusions}

417 The behaviour of different materials for chlorine retention in PVC pyrolysis was studied.

418 Chemicals removers (Chem- $\mathrm{NaHCO}_{3}, \mathrm{Chem}-\mathrm{CaO}$ and $\left.\mathrm{Chem}-\mathrm{Na}_{2} \mathrm{CO}_{3}-\mathrm{ZnO}\right)$ and adsorbents 419 (Ads- $\mathrm{Al}_{2} \mathrm{O}_{3}-1$, Ads- $\mathrm{Al}_{2} \mathrm{O}_{3}-2$ and Ads-NaX) were mixed with PVC $(1: 1 ;$ wt.) and tested in a 420 thermobalance at pyrolysis conditions $\left(200{ }^{\circ} \mathrm{C} / \mathrm{min}\right.$ heating rate from 50 to $\left.550{ }^{\circ} \mathrm{C}\right)$, and the change in mass measured and resulting chars were analysed. The FTIR technique is shown as a valid tool to follow the consumption of the bases present in the chemical removers and the suppression of the $\mathrm{C}-\mathrm{Cl}$ absorption bands of the $\mathrm{PVC}-\mathrm{CHCl}$ - groups during its pyrolysis, as well as the formation of some chlorine salts $\left(\mathrm{CaCl}_{2}\right.$ and $\left.\mathrm{ZnCl}_{2}\right)$. This gave sufficient evidence to verify the performance of this type of materials in the elimination of $\mathrm{HCl}$ gas. Likewise, while $\mathrm{NaCl}$ did not absorb in the studied FTIR region, the $\mathrm{Na}_{2} \mathrm{CO}_{3}$ consumption in Chem$\mathrm{NaHCO}_{3}$ and $\mathrm{Chem}-\mathrm{Na}_{2} \mathrm{CO}_{3}-\mathrm{ZnO}$ was followed by this technique. Complementing the FTIR technique, chlorine salts $\left(\mathrm{NaCl}, \mathrm{CaCl}_{2}\right.$ and $\left.\mathrm{ZnCl}_{2}\right)$ were confirmed in the corresponding chars by EDS. With a detection limit of $50 \mathrm{ppm}$, the EDS technique is more effective in the quantitative determination of chlorine not released during plastic pyrolysis than other methods when the sample quantities are small and routinely analysed. The transformation observed in the adsorbents by FTIR was minor and mainly due to the thermal transformation of their constituents, although Ads-NaX showed recognizable signals 
of pyrolyzed PVC. According to FTIR and CHN analysis data, the PVC pyrolysis occurs

435

436

437

438

439

440

441

442

443

444 through a clear dehydrochlorination process and the formation of aromatic compounds. Chem$\mathrm{CaO}$ and $\mathrm{Chem}-\mathrm{Na}_{2} \mathrm{CO}_{3}-\mathrm{ZnO}$ had the highest chlorine retention (as the percentage that remains in the char in relation to the starting PVC) with values of 63 and $71 \mathrm{wt} \%$, respectively, although $\mathrm{Chem}-\mathrm{CaO}$ still exhibited the capacity to react more $\mathrm{HCl}$ according to the FTIR results. Among the adsorbents, $\mathrm{Ads}-\mathrm{Al}_{2} \mathrm{O}_{3}-2$ gave the best chlorine retention (19 wt. \%) under the studied operating conditions. Likewise, the TGA data clearly showed the effect of adding a chlorine remover to the pyrolysis of PVC at $550{ }^{\circ} \mathrm{C}$.

\section{Acknowledgement}

The funding to support this research was awarded by Innovate UK Energy Catalyst 4. D.T. is thankful for his contract funded by this Project. Cranfield University thank the technical and material assistance received from the Recycling Technologies Ltd throughout the project and for this publication.

\section{References}

[1] E.L. Teuten, J.M. Saquing, D.R. Knappe, M.A. Barlaz, S. Jonsson, A. Björn, S.J. Rowland, R.C. Thompson, T.S. Galloway and R. Yamashita, Philosophical Transactions of the Royal Society B: Biological Sciences, 364, (2009) 2027.

[2] A. Marongiu, T. Faravelli, G. Bozzano, M. Dente and E. Ranzi, Journal of Analytical and Applied Pyrolysis, 70, (2003) 519.

[3] S.D. Anuar Sharuddin, F. Abnisa, W.M.A. Wan Daud and M.K. Aroua, Energy Conversion and Management, 115, (2016) 308.

[4] J. Yu, L. Sun, C. Ma, Y. Qiao and H. Yao, Waste Management, 48, (2016) 300.

[5] N. Lingaiah, M.A. Uddin, A. Muto, T. Imai and Y. Sakata, Fuel, 80, (2001) 1901. 
[6] M.A. Keane, Journal of Chemical Technology \& Biotechnology, 82, (2007) 787.

460 [7] K.-B. Park, S.-J. Oh, G. Begum and J.-S. Kim, Energy, 157, (2018) 402.

461 [8] H. Bockhorn, J. Hentschel, A. Hornung and U. Hornung, Chemical Engineering Science, 54, (1999) 3043.

[9] A. López, I. de Marco, B.M. Caballero, M.F. Laresgoiti and A. Adrados, Fuel Processing Technology, 92, (2011) 253.

[10] S.M. Al-Salem, A. Antelava, A. Constantinou, G. Manos and A. Dutta, Journal of Environmental Management, 197, (2017) 177.

[11] P. Zhao, N. Huang, J. Li and X. Cui, Fuel Processing Technology, 199, (2020) 106277.

[12] T. Bhaskar, R. Negoro, A. Muto and Y. Sakata, Green Chemistry, 8, (2006) 697.

[13] N. Sophonrat, L. Sandström, R. Svanberg, T. Han, S. Dvinskikh, C.M. Lousada and

W. Yang, Industrial \& Engineering Chemistry Research, 58, (2019) 13960.

[14] S.L. Wong, N. Ngadi, T.A.T. Abdullah and I.M. Inuwa, Renewable and Sustainable Energy Reviews, 50, (2015) 1167. Thermal Analysis and Calorimetry, 115, (2014) 227.

[16] Q. Cao, G. Yuan, L. Yin, D. Chen, P. He and H. Wang, Waste Management, 58, 282.

481

[19] H. Kuramochi, D. Nakajima, S. Goto, K. Sugita, W. Wu and K. Kawamoto, Fuel, 87, 482 (2008) 3155 . 
483

484

485

486

487

488

489

490

491

492

493

494

495

496

497

498

499

500

501

502

503

504

505

506

507

[20] A. Lopez-Urionabarrenechea, I. de Marco, B.M. Caballero, M.F. Laresgoiti and A. Adrados, Journal of Analytical and Applied Pyrolysis, 96, (2012) 54.

[21] M.A. Uddin, T. Bhaskar, J. Kaneko, A. Muto, Y. Sakata and T. Matsui, Fuel, 81, (2002) 1819.

[22] C. Tang, Y.-Z. Wang, Q. Zhou and L. Zheng, Polymer Degradation and Stability, 81, (2003) 89 .

[23] M. Brebu, T. Bhaskar, K. Murai, A. Muto, Y. Sakata and M.A. Uddin, Polymer Degradation and Stability, 87, (2005) 225.

[24] D. Wang, R. Xiao, H. Zhang and G. He, Journal of Analytical and Applied Pyrolysis, 89, (2010) 171.

[25] N. Miskolczi, F. Ateș and N. Borsodi, Bioresource technology, 144, (2013) 370.

[26] C. Santella, L. Cafiero, D. De Angelis, F. La Marca, R. Tuffi and S. Vecchio Ciprioti, Waste Management, 54, (2016) 143.

[27] A. Veksha, A. Giannis, W.-D. Oh, V.W.C. Chang and G. Lisak, Fuel Processing Technology, 170, (2018) 13.

[28] B. Fekhar, L. Gombor and N. Miskolczi, Journal of the Energy Institute, 92, (2019) 1270.

[29] A. Lopez-Urionabarrenechea, I. de Marco, B.M. Caballero, M.F. Laresgoiti and A. Adrados, Fuel Processing Technology, 137, (2015) 229.

[30] M. Daoudi and J.K. Walters, The Chemical Engineering Journal, 47, (1991) 11.

[31] W. Wang, Z. Ye and I. Bjerle, Fuel, 75, (1996) 207.

[32] W. Kaminsky and J.-S. Kim, Journal of Analytical and Applied Pyrolysis, 51, (1999) 127.

[33] M. Li, H. Shaw and C.-L. Yang, Industrial \& Engineering Chemistry Research, 39, (2000) 1898. 
[34] Y. Masuda, T. Uda, O. Terakado and M. Hirasawa, Journal of Analytical and Applied Pyrolysis, 77, (2006) 159.

[35] K.-Y. Chiang, J.-C. Jih and K.-L. Lin, Journal of Hazardous Materials, 157, (2008) 170.

[36] T. Kameda, N. Uchiyama, K.-S. Park, G. Grause and T. Yoshioka, Chemosphere, 73, (2008) 844 .

[37] H.M. Zhu, X.G. Jiang, J.H. Yan, Y. Chi and K.F. Cen, Journal of Analytical and Applied Pyrolysis, 82, (2008) 1.

[38] C.-S. Chyang, Y.-L. Han and Z.-C. Zhong, Energy \& Fuels, 23, (2009) 3948.

[39] C.-S. Chyang, Y.-L. Han, L.-W. Wu, H.-P. Wan, H.-T. Lee and Y.-H. Chang, Waste Management, 30, (2010) 1334.

[40] Z. Sun, F.-C. Yu, F. Li, S. Li and L.-S. Fan, Industrial \& Engineering Chemistry Research, 50, (2011) 6034.

[41] S. Kumagai, I. Hasegawa, G. Grause, T. Kameda and T. Yoshioka, Journal of Analytical and Applied Pyrolysis, 113, (2015) 584.

[42] S. Pachitsas, L. Skaarup Jensen, S. Wedel, J. Boll Illerup and K. Dam-Johansen, Journal of Environmental Chemical Engineering, 7, (2019) 102869.

[43] M. Al-Harahsheh, A. Al-Otoom, L. Al-Makhadmah, I.E. Hamilton, S. Kingman, S. Al-Asheh and M. Hararah, Journal of Hazardous Materials, 299, (2015) 425.

[44] J. Zhou, B. Gui, Y. Qiao, J. Zhang, W. Wang, H. Yao, Y. Yu and M. Xu, Fuel, 166, (2016) 526.

[45] T. Yoshioka, T. Kameda, S. Imai and A. Okuwaki, Polymer Degradation and Stability, 93, (2008) 1138.

[46] R.R. Stromberg, S. Straus and B.G. Achhammer, J. Res. Natl. Bur. Stand., 60, (1958) 147. 
[47] M. Theodorou and B. Jasse, Journal of Polymer Science: Polymer Physics Edition, 21, (1983) 2263.

[48] E. Pretsch, P. Bühlmann and M. Badertscher, Structure Determination of Organic Compounds. Tables of Spectral Data, Springer-Verlag Berlin Heidelberg, 2009, p. XV.

[49] J. Wu, T. Chen, X. Luo, D. Han, Z. Wang and J. Wu, Waste Management, 34, (2014) 676.

[50] T. Li, P. Zhao, M. Lei and Z. Li, Applied Sciences, 7, (2017) 256.

[51] D.J. Fray, Plastics, Rubber and Composites, 28, (1999) 327.

[52] K. Sharma, A. Vyas and S.K. Singh, Catalyst, 1, (2015) 200.

[53] X. Ren, E. Rokni, Y. Liu and Y.A. Levendis, Journal of Energy Engineering, 144, (2018) 04018045.

[54] T. Baird, J.R. Fryer and B. Grant, Carbon, 12, (1974) 591.

[55] S. Hosseini, A. Niaei and S. D., Open J. Phys. Chem., 1, (2011) 23.

[56] S. Joshi, S. Kalyanasundaram and V. Balasubramanian, Applied Spectroscopy, 67, (2013) 841 .

[57] M. Kooti and A. Naghdi Sedeh, Journal of Chemistry, 2013, (2013) 4.

[58] T.N. Tran, T.V. Anh Pham, M.L. Phung Le, T.P. Thoa Nguyen and V.M. Tran, Advances in Natural Sciences: Nanoscience and Nanotechnology, 4, (2013) 045007.

[59] M.Z.M. Noor, N.A. Sollahunddin and S. Irawan, Proceedings, 2, (2018) 1273.

[60] P. Raizada, P. Shandilya, P. Singh and P. Thakur, Journal of Taibah University for Science, 11, (2017) 689.

[61] T. Kalaycı and B. Bardakçı, Protection of Metals and Physical Chemistry of Surfaces, 50, (2014) 709 . 
[62] W. Rongchapo, C. Keawkumay, N. Osakoo, K. Deekamwong, N. Chanlek, S. Prayoonpokarach and J. Wittayakun, Adsorption Science \& Technology, 36, (2018)

559 684.

560 [63] F. Iskandar, N.A. Zen, T.R. Mayangsari, A.H. Aimon and A.A. Pramana, Materials $561 \quad$ Research Express, 6, (2019) 045510.

[64] E.K. Tiburu, M. Mutocheluh, P.K. Arthur, P.W. Narkwa, A.A. Salifu, M.A. Agyei, R. Yeboah, H.N.A. Fleischer, J. Zhuang and G. Awandare, Journal of Biomaterials and Tissue Engineering, 7, (2017) 544.

[65] O. Yasar-Inceoglu, T. Lopez, E. Farshihagro and L. Mangolini, Nanotechnology, 23, 566 (2012) 255604 .

[66] J.W. Elam, C.E. Nelson, M.A. Tolbert and S.M. George, Surface Science, 450, (2000) 568 64.

569 [67] R. Sharma, T. Segato, M.-P. Delplancke, H. Terryn, G.V. Baron, J.F.M. Denayer and J. Cousin-Saint-Remi, Chemical Engineering Journal, 381, (2020) 122512.

571 [68] I.É. Gel'ms, V.I. Yuzefovich and R.N. Yudinson, Chemistry and Technology of Fuels 572 and Oils, 3, (1967) 631. 